\title{
TREATMENT OF ELDERLY PATIENTS WITH CHRONIC HEPATITIS C: A RETROSPECTIVE COHORT STUDY
}

\author{
Neven Papić ${ }^{1,2}$, Jelena Budimir ${ }^{1}$, Ivan Kurelac ${ }^{1}$, Davorka Dušek ${ }^{1,2}$, Davor Jugović 2 , \\ Nina Krajcar ${ }^{3}$ and Adriana Vince ${ }^{1,2}$ \\ ${ }^{1}$ Department for Viral Hepatitis, Dr. Fran Mihaljević University Hospital for Infectious Diseases, Zagreb, Croatia; \\ ${ }^{2}$ School of Medicine, University of Zagreb, Zagreb, Croatia; ${ }^{3}$ Department for Pediatric Infectious Diseases, \\ Dr. Fran Mihaljević University Hospital for Infectious Diseases, Zagreb, Croatia
}

\begin{abstract}
SUMMARY - The prevalence of chronic hepatitis $\mathrm{C}$ increases in elderly patients. The aims of this study were to identify the factors associated with hepatocellular carcinoma (HCC) and end-stage liver disease development and to evaluate the efficacy and safety of pegylated interferon (PEG-IFN ) plus ribavirin (RBV) therapy in elderly patients. A retrospective cohort study included all consecutive patients with hepatitis $C$ virus (HCV) infection treated with PEG-IFN $\alpha+R B V$ between 2003 and 2013. Elderly patients had a higher frequency of poor prognostic factors including genotype 1 infection, high fibrosis, and high fibrosis index based on four factors (FIB-4) score. The sustained virologic response (SVR) rate for genotype 1 was significantly lower (35.8\% vs. 57.1\%), while the frequency of PEG-IFN $\alpha$ (27.2\% vs. 7.8\%), RBV dose reduction (19.6\% vs. 9.7\%) and treatment discontinuation (13.0\% vs. 4.1\%) was significantly higher in elderly patients. However, age was not associated with SVR in multivariate analysis, and comparable SVR rates were achieved when adjusted for fibrosis score (Ishak $\leq 3: 66.7 \%$ vs. 69.8\%). During the follow-up, HCC was diagnosed in 18 elderly patients (3 SVR+, 4 SVR- and 9 untreated patients). In conclusion, selected elderly patients can achieve comparable SVR rates as younger patients, but with a higher rate of side effects. Since complications of HCV infection occur more frequently in elderly patients, they should be given priority for antiviral therapy.

Key words: Hepatitis $C$, chronic - treatment; End stage liver disease; Aged; Hepatitis $C$ - prognosis; Pegylated interferon alpha; Immunotherapy; Antiviral agents
\end{abstract}

\section{Introduction}

Chronic hepatitis $\mathrm{C}(\mathrm{CHC})$ continues to be a major public health problem. Despite the limited number of population-based studies on the age-specific prevalence, $\mathrm{HCV}$ prevalence increases with age, and currently the age group with the peak prevalence in $\mathrm{Eu}-$ rope is the $55-65$ age group ${ }^{1,2}$. While the mean life expectancy in the European Union (EU) is 19.8 years once a man reaches the age of 65 (according to the

Correspondence to: Neven Papic, $M D, P h D$, Dr. Fran Mihaljević University Hospital for Infectious Diseases, Mirogojska 8, HR10000 Zagreb, Croatia

E-mail: npapic@bfm.hr

Received August 17, 2016, accepted June 26, 2017
EuroStat), it is expected that HCV related liver cirrhosis and hepatocellular carcinoma (HCC) will dramatically increase in the following years, particularly in the elderly population ${ }^{3}$.

Aging is considered as an unfavorable factor for liver disease progression; adults older than 60 more often present with complications of cirrhosis and $\mathrm{HCC}$ as initial manifestations of $\mathrm{HCV}$ infection; older age at the time of initial infection is associated with more rapid progression to fibrosis, cirrhosis and infectious complications; elderly patients are at an increased risk of HCC, even if they achieve sustained viral response (SVR) in the absence of significant fibrosis or cirrho$\operatorname{sis}^{4-6}$. Although this age group was excluded from the initial pegylated interferon plus ribavirin (PEG- 
IFN $\alpha+\mathrm{RBV}$ ) registration trials, these studies identified age $\geq 60$ years to be associated with poorer treatment response ${ }^{7,8}$. The safety and efficacy of $\mathrm{HCV}$ therapies have been extensively studied in patients between the ages of 18 and 60, but elderly patients remain an understudied and difficult-to-treat population. The 'real-life' studies of PEG-IFN $\alpha+$ RBV treatment in elderly individuals are scarce. Although generally thought as a negative predictor of SVR, the published results of therapy efficacy in elderly patients are disagreeing. While some studies showed the treatment to be well tolerated and there was little or no difference in SVR, other showed marked reduction in SVR rates ${ }^{6}$, 9-12. Nevertheless, older age is still associated with a lower likelihood of being considered for antiviral therapy $^{13,14}$.

Not long ago, direct acting antiviral agents (DAAs) that markedly increase SVR have been licensed, but the efficacy and toxicity of these drugs in elderly population is still unknown. Importantly, due to the price concerns, it is unlikely that this treatment will soon become widely available in low-income countries. Thus, the ways of stratifying patients that might benefit from PEG-IFN $\alpha+$ RBV backbone therapy are of high importance.

Therefore, we performed a retrospective cohort study to examine disease progression in elderly patients treated with PEG-IFN $\alpha+R B V$ as compared with treatment naïve elderly patients and to identify factors associated with HCC and end-stage liver disease (ESLD) development. The secondary aim was to evaluate PEG-IFN $\alpha+\mathrm{RBV}$ treatment response and safety in elderly patients ( $\geq 60$ years).

\section{Patients and Methods}

\section{Study design and population}

In order to analyze treatment response and safety profile of PEG-IFN $\alpha$ and RBV combination therapy in elderly population, a retrospective cohort study that included 577 consecutive adult, treatment-naïve patients that started combination therapy between January 2003 and January 2013 was conducted at the Croatian Reference Center for Viral Hepatitis, Zagreb, Croatia. Patients were stratified by age into two groups: those aged $\geq 60(n=92,15.9 \%)$ and those aged $<60$ years $(n=485,84.1 \%)$.
To determine the impact of PEG-IFN $\alpha+\mathrm{RBV}$ treatment and achievement of SVR on the clinical outcomes of $\mathrm{HCV}$ infection in elderly population $(\geq 60$ years), all consecutive $\mathrm{CHC}$ patients enrolled between 2003 and 2013 were included in the study. In total, 142 patients were included in the cohort that was followed for $3.56 \pm 1.87$ years. Patients were stratified in three categories: SVR group, non-SVR group and untreated patients. Selected endpoints were development of HCC, ESLD, and progression of liver disease, as measured by the aspartate aminotransferase-to-platelet ratio index (APRI) and fibrosis index based on four factors (FIB-4) scores.

\section{Data collection and definitions}

Records of all patients treated at the Department of Viral Hepatitis, University Hospital for Infectious Diseases, Zagreb (UHID) during the study period were extracted and used for collection of clinical and laboratory data. Patients were treated either with PEG-IFN $\alpha 2 a 180 \mu \mathrm{g} /$ week (n=334, 57.9\%) or PEGIFN $\alpha 2 b 1.5 \mu \mathrm{g} /$ week $(\mathrm{n}=243,42.1 \%)$ plus weight-adjusted RBV. The duration of therapy in HCV genotypes 1 and 4 was 48 weeks, and in genotypes 2 and 3 it was 24 weeks. Therapy was discontinued in patients with genotype 1 and genotype 4 if the viral load decreased by less than $2 \log$ HCV RNA copies/mL at week 12 compared with baseline values and if $\mathrm{HCV}$ RNA was still detectable at week 24.

The following demographic and laboratory data were analyzed: age, gender, baseline hemoglobin concentration, white blood cell count (WBC), absolute neutrophil count (ANC), platelet count, aspartate aminotransferase (AST), alanine aminotransferase (ALT), total serum protein and serum albumin, pretreatment $\mathrm{HCV}$ viremia, and genotype. $\mathrm{HCV}$ RNA quantification was performed by COBAS Ampliprep/ COBAS TaqMan HCV test (Roche Diagnostics, Diagnostic Systems, Pleasanton, CA, USA). HCV genotyping was performed by VERSANT HCV Genotyping assay (LIPA, Bayer Diagnostics, Puteaux, Cedex, France). Liver biopsy was performed in a total of 427 patients and the Ishak scoring system was used as an indicator of histologic activity ${ }^{15}$. The APRI and FIB-4 scores were calculated for all patients and were used as a surrogate marker of disease severity ${ }^{16,17}$. The primary outcome measured was SVR achievement defined as undetectable HCV RNA at 24 weeks after the end of 
antiviral therapy. Secondary outcomes were rates of adverse events, rates of PEG-IFN $\alpha$ and/or RBV dose modifications and treatment discontinuation. In order to evaluate disease progression in elderly patients, data on the development of HCC, APRI, FIB-4 score and ESLD were retrieved from medical records of all patients that had $\geq 60$ years at the time of diagnosing HCV at UHID between 2003 and 2013. The diagnosis of HCC was confirmed on the basis of a verified focal liver lesion by imaging techniques in accordance with the European Association for the Study of the Liver guidelines ${ }^{18}$. This study was conducted according to the ethical guidelines of the Declaration of Helsinki and was approved by the UHID Ethics Committee.

\section{Statistical analysis}

Demographic and clinical characteristics and laboratory data were evaluated and presented descriptively. The $\chi^{2}$-test with Yates correction, Fisher exact test and Mann Whitney U test were used to compare the groups, as appropriate. All tests were two-tailed; a $\mathrm{p}<0.05$ was considered statistically significant. Binary logistic regression analysis was used to assess the independent predictors of SVR. Cumulative incidence of HCC was estimated by the Kaplan-Meier method. The prognostic relevance of clinical variables and $\mathrm{HCC}$ occurrence was evaluated by univariate analysis with the log-rank test and by multivariate Cox regression analysis. The time frame for each outcome was defined as the time from diagnosing $\mathrm{HCV}$ infection until the onset of the event. Data were censored when individuals died from non-liver-related causes, received a liver transplant, or were lost during follow-up. The strengths of association were expressed as odds ratio (OR) and the corresponding 95\% confidence interval $(95 \% \mathrm{CI})$. Statistical analyses were performed using Prism (ver. 5.0) statistical software (Graphpad Software, San Diego, CA, USA) and MedCalc for Windows ${ }^{\circledR}$, ver. 11.5.1.0 (MedCalc Software, Mariakerke, Belgium).

\section{Results}

\section{Baseline characteristics of treated patients}

A total of 346 men and 231 women aged 18-73 years $(44.18 \pm 12.6)$ were included in the study. Patients aged $\geq 60$ comprised $15.9 \%$ of the study population.
There were six patients younger than 20, 249 (43.2\%) patients aged 20-39, 118 (20.5\%) patients aged 40-49, $112(19.4 \%)$ patients aged 50-59, 81 (14.0\%) patients aged 60-69, and 11 (1.9\%) patients aged $>70$. Patient baseline characteristics are shown in Table 1.

Elderly patients were more often infected with HCV genotype 1 (88.0\%), had more severe histologic activity of the disease, as well as higher FIB4-score and lower platelet count and hemoglobin level. Importantly, elderly patients more frequently had comorbidities (65.2\%), including hypertension ( $n=42,45.7 \%)$, diabetes $(n=9,9.8 \%)$, chronic obstructive pulmonary disease $(n=10,10.9 \%)$, hyperlipidemia $(n=24,26.1 \%)$, coronary disease $(n=13,14.1 \%)$, and osteoporosis $(n=7$, 7.6\%). Although six (6.5\%) patients had chronic renal impairment, none of our patients was treated with chronic dialysis.

\section{Treatment safety, modifications and discontinuation}

Therapy had to be adapted in a substantial number of elderly patients. Reduction of PEG-IFN $\alpha$ and RBV was more frequently required and treatment was more frequently prematurely discontinued due to side effects in elderly patients. Data on treatment discontinuation and side effects are summarized in Table 2 .

Neutropenia $(\leq 1500$ cells $/ \mu \mathrm{L})$, anemia and thrombocytopenia $\left(\leq 50 \times 10^{9} / \mathrm{L}\right)$ more frequently developed in the elderly group. In addition, during the course of treatment, a decreased level of hemoglobin, ANC and platelets was more pronounced than in younger patients. The mean decrease in hemoglobin was $39.73 \pm 25.71 \mathrm{~g} / \mathrm{L}$ in elderly versus $26.46 \pm 12.33 \mathrm{~g} / \mathrm{L}$ in younger patients $(p=0.0265)$. The incidence of both anxiety and insomnia was higher in elderly patients. There was no lethal outcome in either group during the treatment or in the 6-month follow-up period.

\section{Treatment outcome}

The analysis included data on all patients who received at least one dose of medication (intention-totreat analysis). In the whole group, SVR was achieved in 339 (62.4\%) patients; SVR rate was $53.8 \%$ for genotype 1 and $80.1 \%$ for genotype 3 .

In elderly patients, SVR rate was significantly lower for genotype 1 (35.8\% vs. 57.1\%, p=0.0007), while there was no statistical significance for genotype 3 
Table 1. Baseline patient characteristics

\begin{tabular}{|c|c|c|c|}
\hline & $\geq 60$ years $(n=92)$ & $<60$ years $(n=485)$ & p value ${ }^{b}$ \\
\hline Male sex & $41(44.57 \%)$ & $305(62.89 \%)$ & 0.0016 \\
\hline Age (years) & $63.8 \pm 3.7$ & $40.4 \pm 10.1$ & $<0.0001$ \\
\hline Body weight (kg) & $73.5 \pm 13.43$ & $75.77 \pm 16.82$ & 0.5151 \\
\hline Comorbidities & $60(65.22 \%)$ & $96(19.79 \%)$ & $<0.0001$ \\
\hline Duration of infection (years) ${ }^{\mathrm{a}}$ & $19.86 \pm 12.31$ & $12.35 \pm 9.91$ & 0.0009 \\
\hline \multicolumn{4}{|l|}{ Risk factors } \\
\hline Blood transfusion & $42(45.65 \%)$ & $97(20.00 \%)$ & \multirow{6}{*}{0.0001} \\
\hline Intravenous drug use & $12(13.04 \%)$ & $193(39.79 \%)$ & \\
\hline Surgery/wounding & $15(16.30 \%)$ & $43(8.87 \%)$ & \\
\hline Sexual behavior & $0(0.00 \%)$ & $20(4.12 \%)$ & \\
\hline Other & $1(1.09 \%)$ & $31(6.39 \%)$ & \\
\hline Unknown & $22(23.91 \%)$ & $101(20.82 \%)$ & \\
\hline \multicolumn{4}{|l|}{ Liver biopsy $(\mathrm{n}=427)$} \\
\hline \multicolumn{4}{|l|}{ Ishak score } \\
\hline Ishak 0,1 & $4(6.15 \%)$ & $18(4.97 \%)$ & \multirow{4}{*}{0.0001} \\
\hline Ishak 2,3 & $19(29.23 \%)$ & $230(63.54 \%)$ & \\
\hline Ishak 4,5 & $37(56.92 \%)$ & $108(29.83 \%)$ & \\
\hline Ishak 6 & $5(7.69 \%)$ & $6(1.66) \%$ & \\
\hline \multicolumn{4}{|l|}{ Histology Activity Index (HAI) } \\
\hline HAI 1-8 & $24(36.92 \%)$ & $222(61.33 \%)$ & \multirow{3}{*}{0.0006} \\
\hline HAI 9-12 & $26(40.00 \%)$ & $100(27.62 \%)$ & \\
\hline HAI 13-18 & $15(23.08 \%)$ & $40(11.05 \%)$ & \\
\hline Liver steatosis & $39(60.00 \%)$ & $175(48.34 \%)$ & 0.1055 \\
\hline Moderate/severe steatosis & $21(32.31 \%)$ & $78(21.55 \%)$ & 0.0779 \\
\hline \multicolumn{4}{|l|}{ Genotype } \\
\hline Genotype 1 & $81(88.04 \%)$ & $303(62.47 \%)$ & \multirow{5}{*}{$<0.0001$} \\
\hline Genotype 1a & $8(8.70 \%)$ & $79(16.29 \%)$ & \\
\hline Genotype $1 b$ & $59(64.13 \%)$ & $156(32.16 \%)$ & \\
\hline Genotype 3 & $7(7.61 \%)$ & $156(32.16 \%)$ & \\
\hline Other & $4(4.35 \%)$ & $26(5.36 \%)$ & \\
\hline HCV RNA, log10, IQR & $5.85(5.49-6.3)$ & $5.84(5.23-6.31)$ & 0.3481 \\
\hline$<600,000 \mathrm{IU} / \mathrm{mL}$ & $36(44.44 \%)$ & $173(46.51 \%)$ & 08060 \\
\hline$>600,000 \mathrm{IU} / \mathrm{mL}$ & $45(55.56 \%)$ & $199(53.49 \%)$ & 0.8060 \\
\hline \multicolumn{4}{|l|}{ Biochemical activity } \\
\hline $\operatorname{AST}(\mathrm{IU} / \mathrm{mL})$ & $40.9 \pm 27.21$ & $69.78 \pm 71.13$ & 0.0001 \\
\hline ALT (IU/mL) & $51.31 \pm 49.65$ & $108.2 \pm 125.1$ & $<0.0001$ \\
\hline Platelets (x109/L) & $185.0 \pm 72.86$ & $241.0 \pm 299.1$ & 0.0038 \\
\hline Hemoglobin $(\mathrm{g} / \mathrm{L})$ & $140.0 \pm 12.37$ & $147.5 \pm 14.59$ & 0.0107 \\
\hline APRI score & $0.68 \pm 0.58$ & $0.79 \pm 0.98$ & 0.8552 \\
\hline FIB-4 score & $2.39 \pm 1.43$ & $1.24 \pm 1.03$ & $<0.0001$ \\
\hline
\end{tabular}

${ }^{a}$ Data available for 345 patients; ${ }^{b}$ Fisher exact test or Wilcoxon rank sum test, as appropriate; APRI = aspartate aminotransferase-to-platelet ratio index; FIB-4 = fibrosis index based on four factors 
Table 2. Treatment safety and tolerability

\begin{tabular}{|c|c|c|c|}
\hline & $\geq 60$ years & $<60$ years & p value ${ }^{a}$ \\
\hline \multicolumn{4}{|c|}{$\begin{array}{l}\text { Reported side effects } \\
\text { during PEG-IFN } \alpha \text { therapy }\end{array}$} \\
\hline $\begin{array}{l}\text { Neutropenia, } \\
\mathrm{n}(\%)\end{array}$ & $23(25.00 \%)$ & 53 (10.93\%) & 0.0006 \\
\hline $\begin{array}{l}\operatorname{mean} \pm \mathrm{SD} \\
\left(\mathrm{x} 10^{9} / \mathrm{L}\right)\end{array}$ & $2.5 \pm 0.91$ & $3.2 \pm 1.14$ & 0.0015 \\
\hline Anemia, n (\%) & $29(31.52 \%)$ & 89 (18.35\%) & 0.0069 \\
\hline mean $\pm \mathrm{SD}(\mathrm{g} / \mathrm{L})$ & $107.9 \pm 17.77$ & $117.9 \pm 14.65$ & 0.0018 \\
\hline $\begin{array}{l}\text { Thrombocyto- } \\
\text { penia, n (\%) }\end{array}$ & $32(34.78 \%)$ & $45(9.28 \%)$ & 0.0001 \\
\hline $\begin{array}{l}\text { mean } \pm \mathrm{SD} \\
\left(\mathrm{x} 10^{9} / \mathrm{L}\right)\end{array}$ & $98.7 \pm 48.62$ & $124.7 \pm 46.96$ & 0.0116 \\
\hline $\begin{array}{l}\text { Arthralgia/ } \\
\text { myalgia }\end{array}$ & $12(13.04 \%)$ & 89 (18.35\%) & 0.2941 \\
\hline Dermatologic & $11(11.96 \%)$ & $61(12.58 \%)$ & 1.0000 \\
\hline Respiratory & $3(3.26 \%)$ & $27(5.57 \%)$ & 0.4520 \\
\hline $\begin{array}{l}\text { Hypo/ } \\
\text { hyperthyroidism }\end{array}$ & $3(3.26 \%)$ & $11(2.27 \%)$ & 0.4764 \\
\hline $\begin{array}{l}\text { Flu-like } \\
\text { symptoms }\end{array}$ & $29(31.52 \%)$ & $203(41.86 \%)$ & 0.0649 \\
\hline Anxiety & $42(45.65 \%)$ & $61(12.58 \%)$ & 0.0001 \\
\hline Depression & $4(4.35 \%)$ & $19(3.92 \%)$ & 0.7743 \\
\hline Insomnia & $48(52.17 \%)$ & $39(8.04 \%)$ & 0.0001 \\
\hline Headache & $23(25.00 \%)$ & $103(21.24 \%)$ & 0.4120 \\
\hline \multicolumn{4}{|c|}{$\begin{array}{l}\text { Therapy modification } \\
\text { and discontinuation }\end{array}$} \\
\hline $\begin{array}{l}\mathrm{RBV} \text { dose } \\
\text { reduction }\end{array}$ & $18(19.57 \%)$ & $47(9.69 \%)$ & 0.0107 \\
\hline $\begin{array}{l}\text { PEG-IFN } \alpha \\
\text { dose reduction }\end{array}$ & $25(27.17 \%)$ & $38(7.84 \%)$ & 0.0001 \\
\hline $\begin{array}{l}\text { PEG-IFN } \alpha \\
\text { and RBV dose } \\
\text { reduction }\end{array}$ & $14(15.22 \%)$ & $13(2.68 \%)$ & 0.0001 \\
\hline $\begin{array}{l}\text { Therapy } \\
\text { discontinuation }\end{array}$ & $12(13.04 \%)$ & $20(4.12 \%)$ & 0.0019 \\
\hline
\end{tabular}

${ }^{a}$ Fisher exact test or Wilcoxon rank sum test; $\mathrm{PEG}-\mathrm{IFN} \alpha=$ pegylated interferon alfa; $\mathrm{RBV}=$ ribavirin

(57.1\% vs. $82.0 \%, \mathrm{p}=0.1271)$. Virologic response in young and elderly patients is summarized in Table 3.

However, since the majority of elderly patients had genotype 1 infection and significant fibrosis (Ishak $>3$ ), subgroup analysis was performed and showed no statistical differences in genotype-1 SVR rates when adjusted for fibrosis score (Ishak $\leq 3: 66.7 \%$ (14/21) vs.
Table 3. Treatment response

\begin{tabular}{|l|l|l|l|}
\hline & $\geq 60$ years & $<60$ years & $\mathrm{p}$ value \\
\hline $\begin{array}{l}\text { Genotype 1 } \\
\text { SVR }\end{array}$ & $29(35.80 \%)$ & $173(57.10 \%)$ & 0.0007 \\
$\begin{array}{l}\text { Lost } \\
\text { to follow-up }\end{array}$ & $3(3.70 \%)$ & $13(4.29 \%)$ & 1.0000 \\
\hline $\begin{array}{l}\text { Genotype 3 } \\
\text { SVR }\end{array}$ & $5(71.43 \%)$ & $128(82.05 \%)$ & 0.6136 \\
$\begin{array}{l}\text { Lost } \\
\text { to follow-up }\end{array}$ & $0(0.00 \%)$ & $13(8.33 \%)$ & 1.0000 \\
\hline
\end{tabular}

Fisher exact test; SVR = sustained virologic response

69.8\% (169/73), $\mathrm{p}=0.8016$, and Ishak $\geq 4: 29.7 \%$ (11/36) vs. 43.6\% (44/101, $\mathrm{p}=0.1714)$.

\section{Factors associated with sustained viral response}

In order to identify if age $\geq 60$ is independently associated with lower SVR, we performed multiple logistic regression analysis taking confounders into account. All predictors were entered in a backward stepwise logistic regression model with the SVR being the dependent variable (antiviral therapy (PEG-IFN $\alpha 2 \mathrm{a}$ vs. PEG-IFNa2b), age (<60 years vs. $\geq 60$ years), gender, body weight ( $\leq 75 \mathrm{~kg}$ vs. $>75 \mathrm{~kg}), \mathrm{HCV}$-genotype 3 vs. non-3, extent of fibrosis (mild fibrosis: Ishak 0-3 vs. significant fibrosis: Ishak 4-6)). Statistically nonsignificant predictors were progressively excluded based on the likelihood ratio test. Multivariable model showed that age had no significant influence on SVR. As expected, the best SVR predictor was genotype 3, while significant fibrosis and RBV reduction were negatively associated with SVR, as shown in Table 4.

Similar results were obtained in subgroup analysis that focused on genotype 1, significant fibrosis and $\mathrm{RBV}$ reduction. When only genotype 1 patients were included, fibrosis (OR 0.26, 95\%CI 0.15-0.45, $\mathrm{p}<0.0001$ ) and RBV reduction (OR 0.37, 95\%CI 0.18-0.77, $\mathrm{p}=0.0074$ ) had a negative impact on SVR, while PEG-IFN $\alpha$-2a treatment was positively associated with SVR (OR 1.99, 95\%CI 1.15-3.43, p<0.0132). Next, we performed subgroup analysis on patients with significant fibrosis (Ishak $\geq 4$ ). The final multivariable model included genotype 3 (OR 17.75 , 95\%CI 2.06-152.28), PEG-IFN $\alpha$ reduction (OR 0.09, 95\%CI 0.01-0.75) and female sex (OR 2.62, 95\%CI 1.266.70), but again age was not found to be an independent predictor of SVR. 
Table 4. Factors associated with sustained virologic response

\begin{tabular}{|l|l|l|l|l|}
\hline \multicolumn{2}{|l|}{} & \multicolumn{2}{|l|}{ Univariate analysis } & \multicolumn{2}{l|}{ Multivariate analysis } \\
\cline { 2 - 5 } & $\begin{array}{l}\text { Odds ratio } \\
(95 \% \mathrm{CI})\end{array}$ & p value & $\begin{array}{l}\text { Adjusted odds ratio } \\
(95 \% \mathrm{CI})\end{array}$ & p value \\
\hline Age $\geq 60$ & $0.22(0.11-0.44)$ & $<0.0001$ & & \\
FIB-4 $>3.25$ & $0.14(0.02-0.93)$ & 0.0418 & & \\
Fibrosis $($ Ishak $\geq 4)$ & $0.34(0.22-0.54)$ & $<0.0001$ & $0.34(0.20-0.56)$ & 0.0001 \\
Genotype 3 & $6.89(3.81-12.45)$ & $<0.0001$ & $8.68(3.83-19.64)$ & $<0.0001$ \\
PEG-IFN $\alpha-2 a$ & $1.50(1.02-2.20)$ & 0.0390 & & \\
RBV reduction & $0.34(0.21-0.56)$ & $<0.0001$ & $0.46(0.24-0.90)$ & 0.0238 \\
PEG-IFN $\alpha$ reduction & $0.37(0.20-0.68)$ & 0.0016 & & \\
\hline
\end{tabular}

PEG-IFN $\alpha=$ pegylated interferon alfa; $\mathrm{RBV}=$ ribavirin; $95 \% \mathrm{CI}=95 \%$ confidence interval

\section{Incidence of heptatocellular carcinoma and disease progression in elderly patients}

Of the 577 patients that received PEG-IFN $\alpha+R B V$ treatment in the study period, 256 (44.4\%) patients were followed-up for more than 12 months after the end of treatment (98 SVR+ and 158 SVR- patients, with the mean follow-up of $4.57 \pm 2.71$ years). Seventeen patients developed HCC at the mean age of $56.21 \pm 11.66$ years, corresponding to the incidence rate of 1.95 per 100 person-years. HCC was diagnosed in four patients that achieved SVR; in two patients within 1 year after SVR, and in the other two at 3 and 4 years, respectively, after achieving SVR. HCV RNA was tested at the diagnosis of HCC in all four of these patients, and they all were negative; two patients had Ishak fibrosis score 3, one patient had Ishak 4 and one Ishak 5; none had varices or decompensated liver disease at the time of HCC diagnosis. FIB-4 score $>3.25$ (HR 4.57, 95\%CI 1.65-12.61, $\mathrm{p}=0.0035$ ) and age $\geq 60$ (HR 10.56, 95\%CI 2.64-42.15, $\mathrm{p}=0.0009$ ) were found to significantly influence HCC incidence.

To further determine the impact of PEGIFN $\alpha+\mathrm{RBV}$ treatment on the clinical outcomes of $\mathrm{HCV}$ infection in elderly population, we collected additional data from untreated $\mathrm{CHC}$ patients that were aged $\geq 60$ at the time of first presentation at UHID between 2003 and 2013 and that were followed-up for at least 12 months. Overall, 142 patients were identified and included in the cohort (76 untreated and 66 treated) that was followed-up for $3.56 \pm 1.87$ years. During the follow-up, HCC developed in three patients with SVR, four patients from non-SVR group and nine untreated patients, corresponding to the inci-

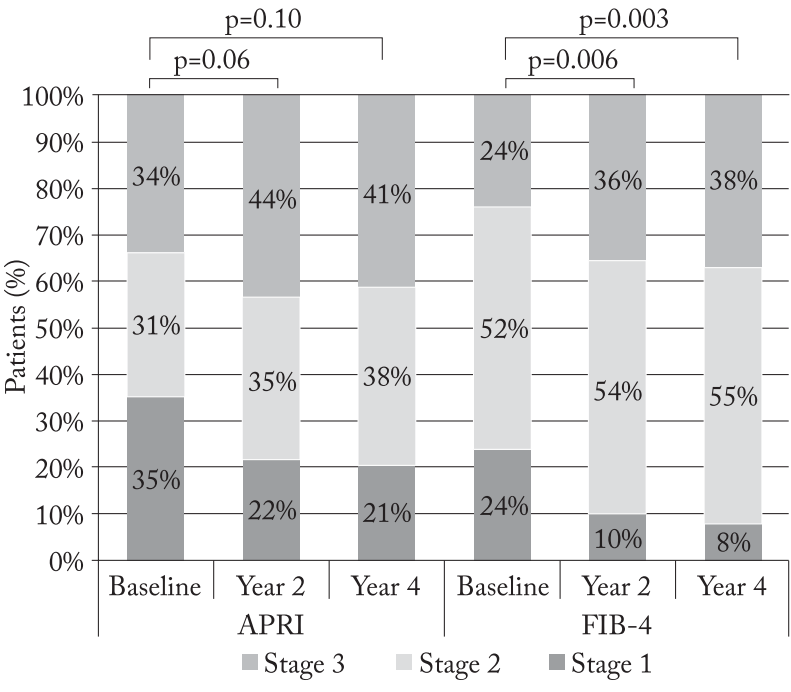

Fig. 1. Progression of liver disease in elderly patients as measured by APRI and FIB-4 score.

Frequencies of HCV infected elderly patients (combined SVR negative and treatment naïv) in different APRI and FIB-4 stages at baseline, year 2 and year 4 of follow-up are shown. A significant increase in stage $3 \mathrm{FIB}-4$ score was recorded between baseline and year $2\left(\mathrm{p}=0.006, \chi^{2}\right.$-test $)$ and year $4(\mathrm{p}=0.003)$.

APRI: stage $1<0.5$, stage $2 \geq 0.5<1.0$, stage $3 \geq 1.0$;

FIB-4: stage $1<1.45$, stage $2 \geq 1.45<3.25$, stage $3 \geq 3.25$.

APRI $=$ aspartate aminotransferase-to-platelet ratio index; FIB-4 = fibrosis index based on four factors

dence of 3.6, 4.7 and 5.0 per 100 person-years, respectively. Cox proportional hazard regression analysis identified only baseline FIB-4 >3.25 (HR 12.1, 95\%CI 3.78-38.71, $\mathrm{p}<0.0001)$ to be independently associated with HCC development, while sex, PEG-IFN $\alpha+\mathrm{RBV}$ treatment and SVR were not associated with $\mathrm{HCC}$ in elderly patients. 
Of 142 patients enrolled, 111 (78.1\%) and 86 (60.5\%) patients had both year 2 and year 4 APRI and FIB-4 levels available, respectively. There were no significant differences in APRI and FIB-4 progression between non-SVR and untreated patients; during 4 years, the proportion of patients with stage 3 APRI $(>1.0)$ and FIB-4 (>3.25) increased from $34 \%$ and $24 \%$ at baseline to $41 \%$ and $38 \%$ at year 4 , respectively (Fig. 1). Any event of disease decompensation (ascites, encephalopathy and/or variceal bleeding) developed in one patient from non-SVR group and in seven (9.21\%) untreated patients.

\section{Discussion}

The combination of pegylated interferon and ribavirin still remains the backbone or even standard therapy in many resource-limited settings. Since the access to IFN free treatment is restricted, the way of prioritizing patients for treatment is of high importance. Interestingly, neither EASL nor AASLD in recently updated HCV treatment guidelines highlight elderly population for early treatment, reflecting the deficiency of studies performed in this understudied group ${ }^{19,20}$.

While the safety and efficacy of PEG-IFN $\alpha+$ RBV therapy have been extensively reviewed, the perception of poorer outcomes and the potential difficulties associated with adherence and drug interactions have resulted in limited access for elderly patients. Results of our study show that older age is associated with several negative predictors of treatment response, such as higher fibrosis score, FIB-4 score, genotype 1 infection and longer duration of infection. This is in clear contrast to other risk groups in Croatia, traditionally considered 'difficult-to-treat', such as war veterans or intravenous drug users ${ }^{21,22}$. In addition, more comorbidities have been observed in elderly patients, mainly metabolic and cardiovascular diseases. According to multivariate analysis, significant fibrosis, RBV reduction and genotype 1 , but not the age, were associated with SVR. Response rates were high among elderly patients with genotype 1 infection and mild fibrosis (66\%) and comparable with younger group. Similar results have been reported from France, Italy, Canada and the USA ${ }^{6,10,12,23}$. Meanwhile, reports from Japan consistently report lower SVR rates in elderly patients ${ }^{11,13}$. Although some of these studies had been performed before IL28B genotyping was recommend- ed, this difference in response rates might be explained with differences in gene polymorphisms. Since the majority of patients from our cohort had been treated before IL28B genotyping was introduced, we did not include IL28B genotype in our analysis.

Huang et al. suggest that poor adherence is the major reason for treatment inferiority in elderly patients and that SVR of $67 \%$ and $80 \%$ can be reached in genotype 1 infected elderly patients, if their treatment lasts for $\geq 80 \%$ of its expected duration and if they achieve rapid virologic response (RVR), respectively ${ }^{24}$. In addition, analysis of our genotype 1 subgroup showed that fibrosis, RBV dose reduction and treatment with PEG-IFN $\alpha$-2a, but not the age, were independent factors associated with treatment efficacy.

The results of our study also confirmed that elderly patients had a higher incidence of dose reduction, mainly due to neutropenia, thrombocytopenia and anemia $^{10,23,24}$. The most frequent age-specific side effects were anxiety and insomnia in up to $52 \%$ of elderly patients, but in contrast to other studies, severe depression occurred in a minority of elderly patients $(4 \%)^{23-25}$. Importantly, treatment completion rate in our study was $86.9 \%$ in the elderly and $95.9 \%$ in the younger group. These rates are significantly higher than previously reported in similar 'real-life' studies that had treatment discontinuation rate of $21 \%$ to $53 \%^{10,24}$. Overall, it seems that selected elderly patients can be treated with PEG-IFN $\alpha+R B V$ therapy, and achieve similar response rates as younger patients, with careful monitoring and management of more frequent side effects. Nevertheless, PEG-IFN $\alpha+$ RBV still remains an option for genotype 1 infected patients with positive predictors of treatment response (RVR, F1F2 fibrosis and IL28 CC genotype) in many countries.

The long-term benefits of virologic cure are well known; SVR is associated with a more than $70 \%$ reduction in the risk of $\mathrm{HCC}$ and $90 \%$ reduction in the risk of liver-related mortality and liver transplanta$\operatorname{tion}^{26-28}$. However, the impact of age on HCV eradication and HCC development is still debatable. The mean age of HCC patients has been progressively increasing over the last decades and in Europe it is currently reaching a peak at 70 years ${ }^{18}$. We examined the occurrence of HCC in our treated cohort that corresponds to the incidence of 1.95 per 100 person-years. While FIB- 4 score $>3.25$ and age $\geq 60$ were significantly associated with HCC development, SVR did 
not significantly reduce the incidence of HCC. Several studies have previously reported that advanced age at $\mathrm{HCV}$ eradication is a risk factor for HCC development in SVR patients ${ }^{5,26,27}$. Bruno et al. report that male sex and age $>54$ have a higher risk of developing HCC after SVR, suggesting that host-related factors and duration of the infection increase the risk of $\mathrm{HCC}^{29}$. Similarly, a study from Japan identified age $>55$ at $\mathrm{HCV}$ eradication and heavy alcohol intake to be independently associated with the development of $\mathrm{HCC}$ within 5 years after $\mathrm{HCV}$ eradication, but longterm risk of developing HCC remains for up to 15 years ${ }^{30}$. Our study showed that in elderly population, the risk of $\mathrm{HCC}$ was higher in both treated and naive patients as compared with younger patients, thus highlighting this population and the importance of early antiviral treatment in this group. Importantly, a proportion of patients with FIB-4 $>3.25$ significantly increased in a 4-year period, increasing this risk even more. Recent reports argue the earlier initiation of treatment in patients with Metavir F0 and F1, which are recognized in current guidelines as a group in which treatment can be postponed; a long-term follow-up study recorded significantly better 15 -year survival rates for SVR patients than for those whose treatment had failed or for those who remained untreated ${ }^{31}$.

The retrospective nature of this study may have represented a potential source of selection bias that might overestimate the incidence of HCC and SVR rates since our Center serves as the Referral Center for Viral Hepatitis in Croatia. The significant number of lost-to-follow-up might represent information bias. However, the rates of SVR and HCC incidence in our study were consistent with those obtained in similar studies, as stated above.

In conclusion, the risk of disease progression and $\mathrm{HCC}$ development in elderly patients with $\mathrm{CHC}$ underscores the need for early treatment of this 'difficultto-treat' group. Although elderly patients often have worse prognostic factors and more frequent side effects to PEG-IFN $\alpha+\mathrm{RBV}$ therapy, a subset of elderly patients can be safely treated with close monitoring, and may achieve comparable SVR rates as younger patients. Since older age is strongly associated with faster fibrosis progression, HCC and reduced quality of life, elderly patients should not be excluded from assessment for treatment a priori. In the Croatian $\mathrm{HCV}$ treatment guidelines, elderly patients are now prioritized for antiviral therapy. Due to the persistent longterm risk of $\mathrm{HCC}$ in elderly patients, even after achievement of SVR, surveillance should be continued over a prolonged period.

\section{References}

1. Esteban JI, Sauleda S, Quer J. The changing epidemiology of hepatitis C virus infection in Europe. J Hepatol. 2008;48(1): 148-62, http://dx.doi.org10.1016/j.jhep.2007.07.033

2. Mohd Hanafiah K, Groeger J, Flaxman AD, Wiersma ST. Global epidemiology of hepatitis $\mathrm{C}$ virus infection: new estimates of age-specific antibody to HCV seroprevalence. Hepatology. 2013;57(4):1333-42, http://dx.doi.org10.1002/hep.26141

3. Razavi H, Waked I, Sarrazin C, Myers RP, Idilman R, Calinas $\mathrm{F}$, et al. The present and future disease burden of hepatitis $\mathrm{C}$ virus $(\mathrm{HCV})$ infection with today's treatment paradigm. J Viral Hepat. 2014;21 Suppl 1:34-59, http://dx.doi.org10.1111/jvh.12248

4. Gunjača I, Francetić I. Prevalence and clinical outcome of spontaneous bacterial peritonitis in hospitalized patients with liver cirrhosis: a prospective observational study in central part of Croatia. Acta Clin Croat. 2010;49(1):11-8.

5. Kobayashi S, Takeda T, Enomoto M, Tamori A, Kawada N, $\mathrm{Habu} \mathrm{D}$, et al. Development of hepatocellular carcinoma in patients with chronic hepatitis $\mathrm{C}$ who had a sustained virological response to interferon therapy: a multicenter, retrospective cohort study of 1124 patients. Liver Int. 2007;27(2):186-91, http://dx.doi.org10.1111/j.1478-3231.2006.01406.x

6. Thabut D, Le Calvez S, Thibault V, Massard J, Munteanu M, Di Martino V, et al. Hepatitis C in 6,865 patients 65 yrs or older: a severe and neglected curable disease? Am J Gastroenterol. 2006;101(6):1260-7, http://dx.doi.org10.1111/j.1572-0241.2006.00556.x

7. Fried MW, Shiffman ML, Reddy KR, Smith C, Marinos G, Goncales FL Jr., et al. Peginterferon alfa-2a plus ribavirin for chronic hepatitis C virus infection. N Engl J Med. 2002; 347(13):975-82, http://dx.doi.org10.1056/NEJMoa020047

8. Manns MP, McHutchison JG, Gordon SC, Rustgi VK, Shiffman M, Reindollar $\mathrm{R}$, et al. Peginterferon alfa-2b plus ribavirin compared with interferon alfa- $2 \mathrm{~b}$ plus ribavirin for initial treatment of chronic hepatitis C: a randomised trial. Lancet. 2001; 358(9286):958-65.

9. Floreani A, Minola E, Carderi I, Ferrara F, Rizzotto ER, Baldo V.Are elderly patients poor candidates for pegylated interferon plus ribavirin in the treatment of chronic hepatitis C? J Am Geriatr Soc. 2006;54(3):549-50, http://dx.doi.org10.1111/j.1532-5415.2006.00643_4.x

10. Nudo CG, Wong P, Hilzenrat N, Deschenes M. Elderly patients are at greater risk of cytopenia during antiviral therapy for hepatitis C. Can J Gastroenterol. 2006;20(9):589-92. 
11. Sato I, Shimbo T, Kawasaki Y, Mizokami M, Masaki N. Efficacy and safety of interferon treatment in elderly patients with chronic hepatitis $\mathrm{C}$ in Japan: a retrospective study using the Japanese Interferon Database. Hepatol Res. 2015;45(8): 829-386, http://dx.doi.org10.1111/hepr.12419

12. Reddy KR, Messinger D, Popescu M, Hadziyannis SJ. Peginterferon alpha-2a $(40 \mathrm{kDa})$ and ribavirin: comparable rates of sustained virological response in sub-sets of older and younger HCV genotype 1 patients. J Viral Hepat. 2009;16(10):724-31, http://dx.doi.org10.1111/j.1365-2893.2009.01122.x

13. Iwasaki $Y$, Ikeda H, Araki Y, Osawa T, Kita K, Ando M, et al. Limitation of combination therapy of interferon and ribavirin for older patients with chronic hepatitis C. Hepatology. 2006; 43(1):54-63, http://dx.doi.org10.1002/hep.20984

14. Omata M, Yoshida H, Shiratori Y. Prevention of hepatocellular carcinoma and its recurrence in chronic hepatitis $\mathrm{C}$ patients by interferon therapy. Clin Gastroenterol Hepatol. 2005;3 (10 Suppl 2):S141-3.

15. Ishak K, Baptista A, Bianchi L, Callea F, De Groote J, Gudat F, et al. Histological grading and staging of chronic hepatitis. $\mathrm{J}$ Hepatol. 1995;22(6):696-9.

16. Lin ZH, Xin YN, Dong QJ, Wang Q Jiang XJ, Zhan SH, et al. Performance of the aspartate aminotransferase-to-platelet ratio index for the staging of hepatitis C-related fibrosis: an updated meta-analysis. Hepatology. 2011;53(3):726-36,

http://dx.doi.org10.1002/hep.24105

17. Sterling RK, Lissen E, Clumeck N, Sola R, Correa MC, Montaner J, et al. Development of a simple noninvasive index to predict significant fibrosis in patients with $\mathrm{HIV} / \mathrm{HCV}$ coinfection. Hepatology. 2006;43(6):1317-25, http://dx.doi.org10.1002/hep.21178

18. EASL-EORTC Clinical Practice Guidelines: Management of hepatocellular carcinoma. J Hepatol. 2012;56(4):908-43, http://dx.doi.org10.1016/j.jhep.2011.12.001

19. EASL Recommendations on treatment of hepatitis C 2015. J Hepatol. 2015;63(1):199-236, http://dx.doi.org10.1016/j.jhep.2015.03.025

20. Panel AIHG. Hepatitis C guidance: AASLD-IDSA recommendations for testing, managing, and treating adults infected with hepatitis C virus. Hepatology. 2015;62(3):932-54, http://dx.doi.org10.1002/hep.27950

21. Kurelac I, Papic N, Sakoman S, Orban M, Dusek D, Coric M, et al. Intravenous drug users can achieve a high sustained virological response rate: experience from Croatian Reference Center for Viral Hepatitis. Hepatitis Monthly. 2011;11(12): 986-92.
22. Papić N, Židovec Lepej S, Kurelac I, Čajić V, Budimir J, Dušek $\mathrm{D}$, et al. Treatment of chronic hepatitis $\mathrm{C}$ in Croatian war veterans: experiences from Croatian Reference Center for Viral Hepatitis. Croatian Med J. 2011;52(1):35-40.

23. Antonucci G, Longo MA, Angeletti C, Vairo F, Oliva A, Comandini UV, et al. The effect of age on response to therapy with peginterferon alpha plus ribavirin in a cohort of patients with chronic HCV hepatitis including subjects older than 65 yrs. Am J Gastroenterol. 2007;102(7):1383-91, http://dx.doi.org10.1111/j.1572-0241.2007.01201.x

24. Huang CF, Yang JF, Dai CY, Huang JF, Hou NJ, Hsieh MY, et al. Efficacy and safety of pegylated interferon combined with ribavirin for the treatment of older patients with chronic hepatitis C. J Infect Dis. 2010;201(5):751-9, http://dx.doi.org10.1086/650470

25. Vrbanac DB, Buljan D, Sindik I, Gelo J, Sakoman LN. Psychiatric aspects of hepatitis $C$ treatment. Acta Clin Croat. 2013; 52(3):346-52.

26. Morgan RL, Baack B, Smith BD, Yartel A, Pitasi M, FalckYtter Y. Eradication of hepatitis $\mathrm{C}$ virus infection and the development of hepatocellular carcinoma: a meta-analysis of observational studies. Ann Intern Med. 2013;158(5 Pt 1):329-37, http://dx.doi.org10.7326/0003-4819-158-5-201303050-00005

27. Hirakawa M, Ikeda K, Arase Y, Kawamura Y, Yatsuji H, Hosaka T, et al. Hepatocarcinogenesis following HCV RNA eradication by interferon in chronic hepatitis patients. Intern Med. 2008;47(19):1637-43.

28. van der Meer AJ, Veldt BJ, Feld JJ, Wedemeyer H, Dufour JF, Lammert F, et al. Association between sustained virological response and all-cause mortality among patients with chronic hepatitis C and advanced hepatic fibrosis. JAMA. 2012; 308(24):2584-93, http://dx.doi.org10.1001/jama.2012.144878

29. Bruno S, Stroffolini T, Colombo M, Bollani S, Benvegnu L, Mazzella $G$, et al. Sustained virological response to interferonalpha is associated with improved outcome in $\mathrm{HCV}$-related cirrhosis: a retrospective study. Hepatology. 2007;45(3):579-87, http://dx.doi.org10.1002/hep.21492

30. Nagaoki Y, Aikata H, Miyaki D, Murakami E, Hashimoto Y, Katamura Y, et al. Clinical features and prognosis in patients with hepatocellular carcinoma that developed after hepatitis C virus eradication with interferon therapy. $\mathrm{J}$ Gastroenterol. 2011;46(6):799-808, http://dx.doi.org10.1007/s00535-011-0384-z

31. Jézéquel C, Bardou-Jacquet E, Desille Y, Renard I, Lainé F, Lelan C, et al. Survival of patients infected by chronic hepatitis $\mathrm{C}$ and F0F1 fibrosis at baseline after a 15 -year follow-up. J Hepatol. 2015;62:S589, http://dx.doi.org10.1016/S0168-8278(15)30912-0 


\title{
Sažetak \\ LIJEČENJE STARIJIH BOLESNIKA S KRONIČNIM HEPATITISOM C: RETROSPEKTIVNO KOHORTNO ISTRAŽIVANJE
}

\author{
N. Papić, J. Budimir, I. Kurelac, D. Dušek, D. Jugović, N. Krajcar i A. Vince
}

Učestalost kroničnog hepatitisa $\mathrm{C}(\mathrm{KHC})$ raste u starijim dobnim skupinama. Ciljevi ovoga istraživanja bili su utvrditi čimbenike povezane s razvojem hepatocelularnog karcinoma (HCC) i dekompenzirane jetrene bolesti te procijeniti učinkovitost i sigurnost terapije pegiliranim interferonom (PEG-IFN $\alpha$ ) i ribavirinom (RBV) u starijih bolesnika. Retrospektivna kohortna studija je uključila sve bolesnike s KHC koji su liječeni PEG-IFN $\alpha+$ RBV između 2003. i 2013. godine u Klinici za infektivne bolesti "Dr. Fran Mihaljević". Bolesnici u dobi od $>65$ godina češće su imali nepovoljne prognostičke čimbenike, tj. HCV-1 genotip, uznapredovali stadij fibroze i viši zbir indeksa fibroze zasnovan na četiri čimbenika (fibrosis index based on four factors, FIB-4). Trajni virusološki odgovor (sustained virologic response, SVR) je bio značajno niži (35,8\% prema 57,1\%), dok je učestalost smanjenja doze PEG-IFNa (27,2\% prema 7,8\%), RBV (19,6\% prema 9,7\%) i prekida liječenja (13,0\% prema 4,1\%) bila značajno češća u starijih bolesnika. Dob nije bila povezana sa SVR u multivarijatnoj analizi, a stariji bolesnici su imali podjednaki SVR kao i mlađi bolesnici ovisno o stadiju fibroze (Ishak $\leq 3: 66,7 \%$ prema 69,8\%). Tijekom praćenja HCC je dijagnosticiran u 18 bolesnika u dobi od >65 godina (3 SVR+, 4 SVR-, 9 neliječenih). Zaključno, stariji bolesnici imaju podjednaku vjerojatnost postizanja SVR kao i mlađi, ali uz češće nuspojave. Budući da se komplikacije infekcije virusom hepatitisa $\mathrm{C}$ češće javljaju u ovoj populaciji, stariji bolesnici trebaju imati prednost u primjeni antivirusne terapije.

Ključne riječi: Hepatitis C, kronični - terapija; Terminalni stadij jetrene bolesti; Starija osoba; Hepatitis C-prognoza; Pegilirani interferon alfa; Imunoterapija; Antivirusni lijekovi 